\title{
O DIREITO AO ABORTO EM CASO DE ANENCEFALIA: \\ UMA ANÁLISE ANTROPOLÓGICA DO JULGAMENTO DA ADPF 54 PELO SUPREMO TRIBUNAL FEDERAL
}

Naara Luna ${ }^{1}$

${ }^{1}$ Universidade Federal Rural do Rio de Janeiro, Programa de Pós-Graduação em Ciências Sociais, Seropédica/RJ, Brasil

\section{Introdução}

Este artigo examina o julgamento da Arguição de Descumprimento de Preceito Fundamental 54 (ADPF 54) no Supremo Tribunal Federal referente à antecipação de parto (aborto) em caso de anencefalia com o objetivo de enxergar, através da argumentação contida nos votos dos ministros, eixos estruturantes do sistema de valores da sociedade brasileira, e sua relação com a configuração de valores da modernidade ocidental. O tema do aborto está no vértice da discussão sobre direitos humanos tanto com respeito a direitos atribuídos ao feto, como o direito à vida, como no tocante à esfera de decisão da mulher. Nesse contexto, está em debate a condição de pessoa desses entes fundamentada na configuração individualista de valores da cosmologia ocidental moderna (Dumont 1997), mas integram o pano de fundo da argumentação as dimensões holistas relacionadas ao caráter sagrado da vida e do ser humano (Durkheim 1970, 1989; Dworkin 2003). No caso da anencefalia, a discussão se estende para aspectos como viabilidade, racionalidade e sofrimento dos envolvidos. O artigo analisa os votos dos ministros e o debate do plenário no julgamento da ADPF 54 realizado nos dias 11 e 12 de abril de 2012. 
A antropóloga Debora Diniz pesquisa o tema e desempenha um papel expressivo como ator na arena do debate sobre o aborto no Brasil. Em memória do início desse debate, Diniz (2014) remete ao primeiro alvará concedido em 1989 por um juiz em Ariquemes, Rondônia, autorizando uma mulher a interromper a gestação de feto portador de anencefalia. A difusão dos exames de ultrassonografia permitiu seu diagnóstico pré-natal. Assim, o diagnóstico migrou dos consultórios médicos para as cortes, envolvendo mulheres, médicos e julgadores. Os casos passam a se concentrar em São Paulo, onde médicos geneticistas e especialistas em medicina fetal argumentaram sobre o "descompasso entre o avanço da ciência e a lei" (2014:165). Nessa arena, a oposição expressou com o termo "ladeira escorregadia" o temor de que a autorização do aborto em casos de anencefalia ensejasse a descriminalização irrestrita, acusando de eugenia. Um caso chegou ao STF, mas no julgamento a turma foi avisada do nascimento e morte do bebê, o que configurava perda do objeto. ${ }^{1}$

A ADPF foi um recurso jurídico para possibilitar o julgamento pelo $\mathrm{STF}_{1}^{2}$ uma vez que as gestações terminavam com perda do objeto, antes que o julgamento do caso particular fosse efetivado. Diniz afirma que, ao acompanhar gestantes de fetos com anomalias incompatíveis com a vida, a maioria optava por interromper a gravidez, declarando no hospital ou na corte: "eu quero acabar com isso; eu quero antecipar o parto" (2014:168). Essa expressão inspirou a fórmula "antecipação terapêutica do parto" empregada em processos judiciais no Ministério Público do Distrito Federal e na petição da ADPF 54. Do início dos anos 90 até o início dos anos 2000, estimam-se 3 mil casos nos tribunais pleiteando a intervenção (Diniz 2014:164), nem sempre com decisões judiciais favoráveis. O movimento de pessoas com deficiência se aproximou do debate. Médicos e juízes se sentiam acuados pela acusação de eugenia. ${ }^{3}$ Entre as entidades que podem solicitar a abertura de uma ADPF está a "confederação sindical ou entidade de classe de âmbito nacional", ${ }^{4}$ por isso idealizadores da ação contataram a Confederação Nacional de Trabalhadores da Saúde.

Em 17 de junho de 2004, a Confederação Nacional de Trabalhadores da Saúde ajuizou a ADPF 54 perante o STF visando assegurar às gestantes de anencéfalo o direito de se submeterem à antecipação terapêutica de parto e ao médico a possibilidade de realizá-la, após atestada a anomalia por profissional habilitado, dispensando a autorização prévia judicial. A ação descaracteriza a ilicitude penal dessa interrupção da gravidez argumentando não se enquadrar nos artigos 124, 126, caput e 128, I e II do Código Penal que tratam do aborto provocado pela gestante ou com seu consentimento, e do aborto não punido (Fernandes 2007). Segundo a petição, "antecipação 
terapêutica de parto de anencéfalo não é aborto"5, o que foi fundamentado na inviabilidade do feto. A aplicação do Código Penal à gestação de feto anencefálico violaria os preceitos constitucionais de dignidade da pessoa humana, o princípio da legalidade, liberdade e autonomia da vontade e o direito à saúde (petição:2-4). O ministro Marco Aurélio Mello deferiu a medida liminar em $1^{\circ}$ de julho de 2004, assegurando o direito às gestantes, contudo, em 20 de outubro, o plenário do STF revogou a liminar. Em 27 de abril de 2005, aprovou-se a admissibilidade da ADPF 54 (Fernandes 2007). Após o resultado da Ação de Inconstitucionalidade 3510 (ADI 3510), que autorizou a extração de células-tronco embrionárias de embriões restantes de reprodução assistida, o relator Marco Aurélio Mello convocou audiência pública de instrução, realizada em sessões em 26 e 28 de agosto, e 4 e 16 de setembro de 2008 (Luna 2015).

Após quatro anos, marcou-se o julgamento para 11 de abril de 2012. O relator Marco Aurélio Mello fez um relatório da ação e proferiu seu voto. Proferidos os dez votos, decidiu-se o julgamento em 12 de abril. A análise dessas peças documentais permitirá revelar aspectos do sistema de valores subjacente aos diferentes argumentos.

Este artigo continua a tradição de estudos das representações coletivas inaugurada por Durkheim em As regras do método sociológico (1973), baseando-se na abordagem de Dumont (1997), que opõe duas configurações de valores que caracterizam as sociedades tradicionais e a sociedade moderna. Nas sociedades tradicionais, de configuração holista de valores, o acento está sobre a sociedade como conjunto (ser humano coletivo), o ideal é a organização da sociedade em vista de seus fins; trata-se de ordem, de hierarquia. Nas sociedades modernas, de configuração individualista, o ser humano é elementar, indivisível na forma de ser biológico e de sujeito pensante. Cada ser humano encarna e humanidade inteira e é a medida de todas as coisas. A sociedade é o meio e a vida de cada um é o fim. Essa figura de ser humano é o indivíduo: o ente associal desprovido de relações, fundamento dos valores axiais de igualdade e liberdade presentes na configuração ocidental moderna.

O julgamento representa uma etapa da controvérsia pública acerca do aborto. Uma controvérsia é "um momento de expressão e redefinição de pontos e problemas, os quais permanecem importantes, às vezes até cruciais, na constituição de uma sociedade" (Giumbelli 2002:96). Assim, por meio da análise dessa controvérsia, é possível revelar alguns valores fundamentais da sociedade no Brasil. Os atores da controvérsia são as mulheres grávidas (e suas famílias), médicos e cientistas, agentes que pretendem representar fetos anencefálicos, entre os quais muitos religiosos, e outros sensíveis às 
demandas do movimento de mulheres, além de operadores do Direito: juízes, advogados, promotores. Vários se apresentaram na audiência pública. No julgamento no STF, etapa da controvérsia aqui analisada, informados pela audiência pública, os ministros manifestam-se. Esse julgamento será objeto de análise do presente artigo, examinando a argumentação proferida nos votos dos ministros.

O suporte para acesso aos discursos analisados são fontes textuais: nelas estão "inscritas as informações metodologicamente relevantes e socialmente significativas" (Giumbelli 2002:102). Os votos são discursos proferidos na linguagem do Direito, o que implica desafios de compreensão para uma análise antropológica desses documentos:

El discurso se presenta bajo el signo del saber jurídico, saber que puede producir un encantamiento en tanto está poblado de tecnicismos y categorías que, una vez comprendidos, se presentan con la fuerza de lo autoevidente. Intentar explicar en qué consisten y cómo son aplicados nos debe forzar a tomar distancia, entendiendo que su construcción encierra toda uma suerte de conflictos diversos (Muzzopappa \& Villalta 2011:37-38).

Além da tradução das categorias dessa linguagem específica, os votos representam posições diferentes no debate. Este artigo quer identificar nesses discursos a argumentação acerca do problema do aborto de anencéfalo.

A fim de organizar o material documental no presente artigo, em que há muitos tópicos repetidos, o voto do relator Marco Aurélio Mello servirá de arcabouço para apresentar os argumentos e a fundamentação dos ministros que o acompanharam, acrescentando as colocações mais originais. Em seguida serão apresentados os argumentos contidos nos votos dos ministros que divergiram do relator.

Os argumentos serão analisados a partir da fundamentação: se invocam fundamentos naturais ou de base biológica oriundos da Ciência, se há fundamentação legal ou no Direito, se são argumentos religiosos ou filosóficos. No julgamento se representa a configuração individualista de valores característica da sociedade ocidental moderna, mas certos argumentos espelham valores opostos, da configuração holista ou tradicional.

\section{Voto do relator Marco Aurélio Mello6}

O relator reporta duas informações: 1. "até o ano de 2005, os juízes e tribunais de justiça formalizaram cerca de três mil autorizações para a interrupção gestacional em razão da incompatibilidade do feto com a vida 
extrauterina" (Acórdão:2). 2. Brasil seria o quarto país do mundo em casos de anencefalia (um caso em mil nascimentos). Isso demonstraria a necessidade de o STF se pronunciar.

O objetivo de uma ADPF é fazer interpretar os enunciados da lei conforme a Constituição (:33). No caso, são os artigos 124, 126 e 128, incisos I e II, do Código Penal que tratam do "crime" de aborto, provocado pela própria gestante, com o consentimento desta, e das exceções à punição. O relator diferencia aborto e antecipação de parto, qualificando o viés político e ideológico nas expressões "aborto eugênico ou eugenésico" ou "antecipação eugênica da gestação" (:34). Considera haver conflito entre os interesses legítimos da mulher em ter respeitada sua dignidade e os que desejam proteger os que estão por nascer, independentemente "da condição física ou viabilidade de sobrevivência" (:34).

O relator é original ao não contrapor o direito da mulher e o do feto, mas os interesses da mulher e os de quem diz proteger os "nascituros".

O ministro pergunta se a lei pode obrigar uma mulher a prosseguir a gestação quando não há expectativa de vida para o feto. Pergunta também se a tipificação penal (considerar crime) da interrupção da gravidez de feto anencefálico seria compatível com a Constituição, em particular com os princípios do Estado laico, da dignidade da pessoa humana, do direito à vida, da proteção à autonomia, da liberdade, da privacidade e da saúde (:34). No tocante ao Estado laico, afirma que o Brasil é "Estado secular tolerante com as religiões" (:40). O princípio da laicidade atua de modo duplo: resguarda as confissões religiosas da intervenção abusiva do Estado e protege o Estado de influências do campo religioso (:41). A liberdade religiosa e o Estado laico implicam que as religiões não vão guiar o tratamento estatal a outros direitos fundamentais, como "o direito à autodeterminação, o direito à saúde física e mental, o direito à privacidade, o direito à liberdade de expressão, o direito à liberdade de orientação sexual e o direito à liberdade no campo da reprodução" (:43). Afirma que argumentos de entidades religiosas devem ser 'traduzidos' (aspas no original) "em termos de razões públicas" (:43).

O segundo ponto é a anencefalia, definida como doença letal sem potencialidade de vida extrauterina e distinta da deficiência física, passível de diagnóstico a partir da $12^{\mathrm{a}}$ semana de gestação por meio de ultrassonografia, refutando a acusação de aborto eugênico. Descarta o exemplo de Marcela de Jesus que teve sobrevida excepcional por se tratar de anomalia similar. ${ }^{7}$

Esse argumento da letalidade absoluta e da inviabilidade do anencéfalo para vida extrauterina é central no julgamento e na argumentação dos ministros: a discussão da inviabilidade está presente em todos os votos. A pergunta é se o feto anencefálico é titular de direitos no mesmo grau que a gestante. 
O terceiro ponto, referente à proteção do feto, é a doação de órgãos do anencéfalo. Considera injustificável manter a gravidez para obrigar à doação de órgãos, o que fere a dignidade da mulher por a "coisificar". O estado dos órgãos de um anencéfalo contraindicaria a doação, além disso, para doar, é necessária a idade mínima de sete dias e os bebês falecem antes ${ }^{8}$ (:53-54).

$\mathrm{O}$ quarto ponto trata do direito à vida do anencéfalo. Argumentando por sua inviabilidade, não se poderia invocar o direito à vida. Em vista da impossibilidade de vida, citando o ministro Joaquim Barbosa, o anencéfalo "mesmo que biologicamente vivo" é "juridicamente morto", portanto, a interrupção da gravidez não constitui crime contra a vida (:55). Cita o jurista Nelson Hungria sobre gravidez extrauterina, dizendo que sua interrupção não constitui crime de aborto, na impossibilidade de salvar a vida do feto (:55-56). Segundo o relator, "o feto sem potencialidade de vida não pode ser tutelado pelo tipo penal que protege a vida" (:56).$^{9}$ Cita o voto do relator Carlos Ayres Britto na ADI 3510, para afirmar que, como no caso do embrião que poderia ser destinado à pesquisa com células-tronco, não existe potencialidade para se tornar pessoa humana, portanto, não haveria justificativa para tutela jurídico-penal (:58). Toma o conceito de morte cerebral para afirmar a impropriedade do direito à vida intra ou extrauterina no caso do anencéfalo (:58). Defende o caráter não absoluto do direito à vida. Usa o exemplo do aborto humanitário, quando a gestação é resultado de estupro, aborto permitido de feto viável, portanto, a lei prioriza os direitos da mulher sobre os do feto (:58-59). Afirma haver gradações na proteção do direito à vida, de modo que a tutela desse direito dos anencéfalos seria menos intensa do que a conferida às pessoas e aos fetos em geral (:59-60).

O ponto 5 trata dos direitos da mulher contrapostos aos do feto anencefálico: direito à saúde, à dignidade, à liberdade, à autonomia, à privacidade (:60). O relator cita maior risco à saúde da mulher na gravidez de anencéfalo. ${ }^{10}$ Também é mencionado o dano no aspecto psíquico pela "manutenção compulsória da gravidez". Menciona que obrigar a prosseguir essa gestação seria comparável à tortura. Cita decisão do comitê de direitos humanos da ONU que considerou tratamento "cruel", "inumano e degradante" dado a uma mulher no Peru, cuja autorização para interromper gravidez de feto anencefálico foi negada (:65). Quanto à possibilidade de sentimento de culpa pela interrupção, caberia à mulher decidir, não ao Estado intrometer-se, mas apenas informar e prestar apoio à paciente (:66). Ressalta que não se trata de impor a antecipação de parto, mas que está em jogo o direito da mulher de autodeterminação, sua privacidade, autonomia e dignidade humana (:67). O relator invoca o princípio da proporcionalidade para afirmar que proteger apenas um dos lados da relação, aquele sem 
expectativa de vida extrauterina, representa aniquilar os direitos da mulher, impondo-lhe "sacrifício desarrazoado" (:68). Conclui que, mesmo que se conceda o direito à vida ao anencéfalo, "tal direito cederia [...] em prol dos direitos à dignidade da pessoa humana, à liberdade no campo sexual, à autonomia, à privacidade, à integridade física, psicológica e moral e à saúde", previstos na Constituição ${ }^{11}$ (:69). Vota pela garantia do direito de a mulher se manifestar livremente, sem temer se tornar ré em ação por crime de aborto (:69). Ele julga procedente o pedido e concorda em não tipificar como crime a antecipação terapêutica do parto no caso de anencefalia, pois tal interpretação seria inconstitucional.

O voto do relator privilegia os direitos da mulher: os direitos à saúde, à privacidade e à autonomia são tributários da configuração individualista de valores.

\section{Plenário}

O relator lamenta que em janeiro de 2004 o próprio tribunal tenha lançado as mulheres brasileiras em uma "via crucis" para pleitear em juízo a interrupção da gravidez. Ele percebeu a sensibilidade maior ao tema quando o STF aprovou a pesquisa com células-tronco, então convocou a audiência pública. Segundo o relator, não se trata de aborto, mas de interrupção terapêutica da gravidez para preservar a vida da mulher, pois a gestação de feto anencefálico porta maior risco (:86).

Percebe-se que, quando relata a "via crucis" das mulheres que precisam pleitear na Justiça essa autorização e os elevados números de solicitações judiciais, o ministro vê o caso como problema de saúde pública. Serão enumerados a partir daqui argumentos de diferentes votos, apresentando primeiro os favoráveis à ação, ao direito de escolha das mulheres e depois todos os argumentos contrários à ação e antiaborto. Deve-se salientar que os ministros não debatem a definição de aborto, nem a terminologia adequada (interrupção da gravidez), mas se a antecipação terapêutica de parto (termo empregado na ação) em caso de anencefalia constitui ou não "crime" de aborto previsto no Código Penal. 


\section{Argumentos favoráveis à ação}

\section{Morte encefálica}

O argumento da morte encefálica é repetido e essencial para não enquadrar a antecipação terapêutica de parto de anencéfalo como "crime" de aborto. O ministro Joaquim Barbosa afirma que o feto anencefálico, mesmo biologicamente vivo, não tem proteção jurídica. Quanto à proteção da vida humana através do Direito Penal, defende as teses: "(i) que a vida vegetativa não é suficiente para fazer de algo um homem, e (ii) que com a morte encefálica termina a proteção à vida" (:151).

\section{Início da vida: fundamentos biológicos e fundamentos religiosos}

Celso de Mello aborda teses que procuram estabelecer conceitos bioéticos sobre o início da vida. Ele destaca a variedade de teorias, o que permite optar pela concepção mais ajustada ao interesse público e que respeite os direitos das pessoas, com o objetivo de conferir sentido real ao princípio da dignidade da pessoa humana, além de reconhecer as prerrogativas básicas para qualquer pessoa do direito à vida, do direito à saúde e do direito à liberdade (:349).

Os estudos mencionados mostram o caráter construído da escolha dos fundamentos biológicos e religiosos para o início da vida e como a Natureza é referida nas teorias sobre o início da vida como base da realidade (Laqueur 1992). Uma perspectiva distinta sobre a relação entre a Ciência e o Direito aparece no voto da ministra Rosa Weber.

\section{Fundamentação na Ciência (Biologia) ou no Direito}

A ministra Rosa Weber designa de "falácia naturalista" derivar dever de proteção baseado na descrição de um fato pela Ciência (:94). Afirma que a proteção ou não do feto anencefálico não decorre de critérios adotados pela Medicina em dado momento, mas dos critérios jurídicos concernentes ao conceito de vida. Ela alerta que a Ciência não tem controle total de seus conceitos nem pode pretender estabelecer verdades que obriguem outras áreas do conhecimento, como o Direito. Recupera a história do conceito de morte encefálica: antes dele a Medicina considerava um sujeito morto pelo critério de parada cardiorrespiratória. A ministra afirma que "cada ciência apresenta uma linguagem própria que está em conformidade com 
as condições paradigmáticas aceitas e que é pertinente ao seu campo de atuação e suas pretensões cognitivas" (:102). Ela aplica a noção de paradigma à área do Direito e conclui pela independência do conhecimento jurídico, afirmando que o conceito de vida no Direito deverá ser discutido "de acordo com sua significação própria no âmbito da dogmática jurídica, da legislação e da jurisprudência" (:104).

Assim, a ministra afirma a autonomia do conhecimento jurídico quanto à Ciência, referente ao conceito de vida, para definir a proteção do feto.

\section{Proporcionalidade e ponderação}

O pleito da ADPF 54 mostra choque entre direitos conflitantes. Para lidar com esses casos, vários ministros citaram o postulado da proporcionalidade em que se pergunta pela adequação do meio para solucionar o choque entre os direitos (Júdice 2007).

Ilustra-se esse postulado no voto de Rosa Weber. A ministra expõe uma fórmula da proporcionalidade voltada para a discussão dos dois tipos de direitos constitucionais envolvidos na ADPF 54: direito de proteção contra direito de defesa. Afirma o direito de proteção da gestante contra o Estado, pois este não pode interferir em seu direito de escolha de interromper a gravidez, sob pena de violar a saúde, a liberdade e a integridade da mulher (:131).

O direito de proteção contra o Estado evocado pela ministra é a discussão sobre autonomia, um dos valores mais caros à configuração individualista de valores, característica da modernidade ocidental, conforme visto em Dumont (1997).

Para a ministra, a proteção da vida do anencéfalo fere a liberdade, a integridade física e psicológica da mulher, tanto na esfera da saúde como na esfera da dignidade humana. Se há dúvidas sobre a viabilidade do feto, impor essa gestação contra a vontade da mulher seria tortura física e psicológica (:133). A alegria e a realização das mulheres com filhos anencefálicos decorrem de suas escolhas e da certeza de serem respeitadas e não impedidas de gestar seus filhos. Não está em jogo o direito do feto, mas o direito da mulher viver suas próprias escolhas (:135).

Emprega-se a lei da ponderação quando a colisão de direitos não é solucionada pela aplicação da máxima da proporcionalidade (Júdice 2007) vista acima, daí há a necessidade de avaliar as consequências jurídicas dos princípios em colisão. O raciocínio da ministra Cármen Lúcia exemplifica a ponderação: o aborto necessário não é punido, quando se demanda a interrupção da gravidez se não há outro meio de salvar a vida da mãe. 
Na escolha entre dois bens jurídicos, a vida da gestante e a vida do feto, a opção é pela certeza da vida adulta. A ministra cita o argumento do estado de necessidade que justifica a lesão a um bem jurídico "quando o mal que se causa é menor do que aquele que se evita" (:198).

A prática da ponderação se assemelha ao princípio social da hierarquia descrito por Dumont (1997): hierarquizar é adotar um valor.

\section{Grau de proteção da vida}

Joaquim Barbosa discorre acerca do grau de proteção à vida. Pergunta se, quando a vida extrauterina do nascituro é inviável, caso da anencefalia, o Direito deve garantir o mesmo grau de proteção. Defende que a tutela da vida humana tem graus diferenciados. O ministro discerne três situações: do feto em desenvolvimento, do feto biologicamente morto, e do feto biologicamente vivo, mas juridicamente morto (:151).

Para a presente análise, ele demonstra nesse ponto o embate entre diferentes fundamentos: a vida em termos biológicos não tem necessariamente reconhecimento jurídico.

O ministro afirma que o feto anencefálico, mesmo estando biologicamente vivo, não tem proteção jurídica.

A discrepância no grau de proteção da vida revela-se na comparação feita pela ministra Rosa Weber das penas para os crimes contra a vida no Código Penal e constata uma gradação quanto à proteção da vida como bem jurídico, pois as penas variam, ponto que ilustra a proporcionalidade. A pena para aborto é menor do que a de infanticídio ${ }^{12}$ e esta é menor do que a de homicídio. A pena por aborto é inferior à pena por lesão corporal grave. A situação da mãe ou da gestante no caso de aborto e infanticídio é levada em consideração. Não se pune o aborto em caso de estupro, situação em que o feto é viável e, no entanto, não há interesse em proteger o feto contra a gestante. Ela conclui que, para o direito penal, a vida não é um valor único e absoluto (: 105).

Essa conclusão se choca com o ativismo antiaborto, que coloca a vida do feto como valor supremo, conforme visto na audiência pública (Sales 2015), e a posição dos ministros contrários à ação abordada adiante.

\section{Religião e Estado Iaico}

Apresenta-se a relação entre religião e o princípio de laicidade do Estado desde o início do julgamento. O engajamento de agentes religiosos no debate público sobre aborto é notório (Diniz 2008; Luna 2013), sendo um tema mencionado em abordagens distintas. 
Celso de Mello define a postura do Estado laico: é "proibido, ainda, ao Estado, o exercício de sua atividade com apoio em princípios teológicos", mesmo que "se trate de dogmas consagrados por determinada religião considerada hegemônica no meio social", sob a pena de concepções religiosas se tornarem critério para definir decisões estatais e políticas de governo (:334). A separação constitucional entre Estado e Igreja tem o objetivo de resguardar duas posições: 1 . assegurar a liberdade religiosa; 2 . impedir que grupos fundamentalistas se apropriem do aparelho do Estado para impor aos demais cidadãos a observância de suas diretrizes religiosas (:338).

Já o ministro Gilmar Mendes avalia que os argumentos de organizações religiosas devem ser considerados, porque se relacionam a razões públicas, por isso não impede a manifestação de entidades religiosas nos debates públicos (:271-276). Na abordagem do direito comparado, o debate em países "religiosos"13 enfatiza que a vida intrauterina deve receber proteção estatal e que seus direitos podem se sobrepor aos direitos da gestante.

Percebe-se a transgressão dos limites atribuídos ao Estado laico na declaração do ministro Luiz Fux, ao comentar várias comunicações escritas, e-mails e cartas com o tema do julgamento, fazendo uma declaração pessoal:

Agradeci a Deus por poder contribuir com a humanidade por meio de uma decisão que pode conjurar tristezas, angústias, dores, aflições e, ao mesmo tempo, pedi a Deus que a razão e a paixão me acompanhassem no exercício desse mais alto apostolado que um ser humano pode se dedicar nesse mundo de Deus: a magistratura (:154-155).

Em tempos de debates acalorados sobre o Estado laico, o ministro ousou assumir que agradeceu a Deus tanto pela oportunidade de contribuir na decisão, como pediu a Deus sobre seu exercício na magistratura. O plenário não reagiu à declaração. ${ }^{14}$

A diferente relação com a laicidade expressa nesses três extratos de discursos dos ministros mostra a complexidade do tema, tanto com respeito à tradição republicana que propõe rigorosa separação entre Estado e Igreja e a restrição da influência de autoridades e grupos religiosos na esfera pública, como a tendência oposta de interpretar de modo lato a laicidade a fim de garantir a legitimidade da ocupação religiosa da esfera pública, ou a interpretação na perspectiva multiculturalista de conceder mais espaço à religião (Mariano 2011:252-3). 
Sofrimento: a experiência das gestantes e suas famílias

Outro ponto enfatizado diz respeito ao sofrimento. Os ministros comentam relatos das experiências das gestantes e famílias. O ministro Fux lê carta que relata a dor do casal: a "gestante assistiu durante nove meses ao funeral do seu filho" (:155).

Cármen Lúcia observa que "o útero é o primeiro berço de todo ser humano" (:173), mas nesse caso "o berço se transforma num pequeno esquife". Ela fala de uma relação entre seres: da mãe, que deve lidar com possibilidade da morte antes da vida, e do anencéfalo. Trata-se de uma escolha trágica, segundo a ministra, a escolha da menor dor. Por ser baseada na dignidade da vida, essa interrupção é não criminalizável (:174).

A ministra Cármen Lúcia conclui: “Não há a quem imputar a responsabilidade pela injustiça de uma mulher gestar um feto inviável. A injustiça não está no sofrimento involuntário, mas na tortura do dever da gestação de um feto inviável provocada pelo Estado ao impedi-la de interromper a gestação" (:189). A ministra continua a mencionar o sofrimento das famílias em seu voto: embora alguns tenham convicções religiosas ou filosóficas para sustentar a gestação, outras serão obrigadas a prosseguir com uma gestação sem perspectiva de vida, serão "chamadas a escolher um túmulo e um pequeno caixão enquanto o seu era o sonho de adquirir um berço e um enxoval" (:201).

O sofrimento das mulheres, ao descobrirem a condição irremediável dos fetos que gestam, e das famílias é um dos vetores para mobilizar a opinião pública, bem como dos ministros. A esse respeito cabe a análise de Boltanski acerca do sofrimento à distância e do engajamento do "espectador" do sofrimento em uma causa como se fosse sua:

No ideal do espaço público um sofrimento local pode ser transportado sem deformação, de maneira a se tornar disponível para qualquer um, ou seja, para todos aqueles que - por força da disponibilidade que lhes confere sua ausência de comprometimento prévio - são livres para dele se apropriar, ao se descobrirem concernidos e passarem ao engajamento e à adoção da causa como sua (Boltanski citado em Duarte, 1996).

No julgamento pelo STF de uma ação como a ADPF 54, os sofrimentos individuais cujos relatos foram citados, tornam-se uma causa coletiva à qual a sociedade, por meio do sistema judiciário, precisa responder, conforme ressaltou o relator acima ao informar o impressionante número de três mil autorizações formalizadas nos tribunais (até 2005) para interromper esse tipo de gestação. O grande número de casos registrados mostra o caráter 
social da aflição, uma concepção de sofrimento social, segundo a abordagem de Víctora, vinculado às "políticas e economias da vida, verificadas em condições e configurações históricas e sociais específicas" (2011:6). Com base em Kleinman, Víctora afirma que "uma dimensão importante do sofrimento social está relacionada aos processos políticos e profissionais, os quais podem envolver (1) apropriações autorizadas ou contestadas do sofrimento coletivo; (2) a medicalização da vida; e (3) sofrimento na relação com políticas públicas" (2011:6). No caso do pleito por aborto ou antecipação terapêutica do parto em função da inviabilidade do anencéfalo, o sofrimento social decorre também da contestação do sofrimento pelas autoridades do Estado, tanto por parte do Congresso Nacional em sua omissão para aprovar nova lei como a de juízes que negam as autorizações de aborto no caso, ou dos ministros do Supremo que contestam a aflição dessas mulheres e de suas famílias. Segundo a classificação apresentada por Víctora, o caso corresponderia a dois dos tipos: o primeiro com a apropriação contestada do sofrimento coletivo, e o terceiro por conta da relação com políticas públicas.

\section{Condição de pessoa}

Eis um argumento central, pois a condição de pessoa define se um ente é portador de direitos.

Fux descreve a anencefalia e ressalta as limitações de um anencéfalo "cego, surdo, inconsciente e incapaz de sentir dor" (:156), salientando a impossibilidade total de ganho de consciência em função da ausência do cérebro, bem como a morte logo após o nascimento.

Para a presente análise, é fundamental observar que as limitações do anencéfalo apresentadas pelo ministro no tocante à vida de relação o descaracterizam como um ser humano pleno, em particular com respeito à impossibilidade de ganho de consciência. Essas questões são colocadas em artigos médicos que comparam a anencefalia com a morte cerebral (Penna 2005): a incapacidade de adquirir sensações e a de desenvolver a consciência, mesmo se nascido "vivo", isto é, com batimentos cardíacos, são cruciais para negar que tal feto esteja vivo de fato, e possa ser considerado um ser humano pleno, dotado de direitos. Penna usa a expressão "biologicamente ativo" para os sujeitos em morte cerebral mantidos por respiradores e drogas, ressaltando a diferença entre pessoa morta e organismo vivo, e estende essa categoria aos fetos anencefálicos. 
A pergunta central da ADPF: propriedade da aplicação da lei

Nas palavras do ministro Fux, o Supremo tem que decidir se é justo, sob o aspecto criminal, "colocar uma mulher que, durante nove meses, leva em seu ventre um feto anencefálico, o qual não tem condições de vida, no banco do Júri, porque aborto é crime contra a vida e sujeito à competência do Júri" (:159).

A ministra Cármen Lúcia pondera que, se o Código Penal é omisso quanto ao caso da anencefalia, o magistrado deve ter compreensão quanto à gestante que opta pela interrupção da gravidez nesse caso. A ministra afirma: "Não se há de negar compaixão, porque seria injustiça, menos ainda o direito, porque seria antijurídico, à mulher que, trazendo um pequeno caixão no que é o seu berço físico, vai às portas do Judiciário a suplicar pela sua vida" (:221). ${ }^{15}$

Se, no sentido formal do Direito, a mulher não se enquadra nas exceções à punição, portanto, deveria ser julgada pelo aborto do anencéfalo, ou não poderia pleitear o aborto legal, os ministros Fux e Cármen Lúcia se colocam na perspectiva do Direito material, isto é, da finalidade do Direito: o que ele garante ou exige. ${ }^{16}$ Deve ser considerada a noção de culpa e os graus de culpabilidade relativos à intenção do delinquente (Weber, 1998:503): não se deve atribuir culpa à mulher por antecipar o parto de feto inviável.

\section{Proteção das minorias pelo Estado}

Outro aspecto é considerar o dever do Estado de proteger grupos vulneráveis e minorias, caso das gestantes de fetos anencefálicos. Nesse sentido, o ministro Fux contrapõe o caso ao julgamento da Marcha da Maconha e da união homoafetiva em relação a uma política de reconhecimento da diferença, o que evita marginalização da sociedade civil (:167).

Celso de Mello também alega a "função contramajoritária" do Supremo Tribunal Federal de reconhecer e outorgar proteção a grupos vulneráveis contra excessos da maioria ou contra omissões que se tornem lesivas, diante da inércia do Estado, aos direitos dos que sofrem os efeitos do preconceito e da discriminação jurídica (:358-9). Cita o julgamento da ADI 4.277, referente à união estável homoafetiva, como exemplo da preservação e do reconhecimento de direitos de grupos vulneráveis, da qual a corte é incumbida de velar. Comenta sobre a atuação no Congresso Nacional de grupos majoritários que ensaiaram medidas arbitrárias com o objetivo de frustrar o exercício de direitos assegurados pela Constituição a organizações minoritárias (:359-364). 
Ambos os ministros ressaltam a necessidade de contemplar na interpretação da lei as situações das minorias. Assim, evoca-se a participação do Poder Judiciário em promover maior acesso à justiça e à igualdade de direitos sob o argumento do princípio da democracia, diante da acusação que o Legislativo privilegia os desejos da maioria e cristaliza desigualdades sociais (Coitinho Filho \& Rinaldi, 2018:31-32).

\section{Inviabilidade}

O argumento da inviabilidade é dos mais citados para diferenciar a antecipação terapêutica de parto e o "crime" de aborto.

Joaquim Barbosa, com base na literatura especializada e nos depoimentos da audiência pública, afirma que 50\% dos anencéfalos nascem mortos e os outros 50\% morrem em poucos dias, não sendo possível "vida extrauterina independente" (:147).

O argumento crucial sobre inviabilidade na perspectiva do Direito foi citado pelo relator Marco Aurélio: "o feto sem potencialidade de vida não pode ser tutelado pelo tipo penal que protege a vida" (:56), ou seja, não se protege feto inviável, porque este não seria um vivente conforme o Direito.

\section{Conceito de vida}

A inviabilidade fetal remete à ausência de expectativa de vida extrauterina. É necessário compreender o conceito de vida e se cabe no caso do anencéfalo.

Cármen Lúcia afirma que a vida não deve ser considerada apenas em sua acepção biológica, mas em sua acepção biográfica mais compreensiva. $\mathrm{O}$ direito à vida não deve se restringir à mera subsistência, mas a um modo de viver especificamente humano (:195-197).

É possível comparar o pensamento da ministra com a análise de Waldby (2002:313) acerca da pesquisa com embriões humanos: a vida não deve ser apenas uma vitalidade biológica crua, como a presente nos embriões em estágio inicial próprios para extração das células-tronco e, por analogia na presente análise, no anencéfalo. Tampouco se encontraria nos embriões iniciais, nem no feto anencefálico, uma acepção biográfica de vida, como ponto inicial de uma narrativa que se deve deixar seguir seu curso. Assim, não basta o processo vital: eles deveriam ser pessoas no sentido jurídico ou no antropológico. Waldby e Squier (2003:36) afirmam que a biologia é orientada por alvos (goal-oriented) e que seu alvo é a produção de um sujeito totalmente humano. Esse humano pleno não se efetiva nos embriões de pesquisa, nem nos fetos anencefálicos. 
Falta no caso da anencefalia a pessoa humana na acepção de Mauss (2003), que descreve a construção histórica da noção de pessoa e do eu. ${ }^{17}$

Cármen Lúcia prossegue relacionando o conceito de vida com a condição do anencéfalo. A despeito da inviabilidade de vida extrauterina, há duas correntes: a primeira entende que o anencéfalo apresenta sinais vitais no ventre materno e será titular de direitos desde a concepção (:212). A segunda corrente não o considera titular de direitos, e pela ausência de vida cerebral, seu aborto seria um "crime impossível" (:213). A ministra se alinha com a segunda corrente afirmando a inexistência de aborto de feto anencefálico, pois está ausente o objeto jurídico tutelado (:215), a vida do feto, por isso não haveria "crime" de aborto. O anencéfalo não dispõe de condições para adquirir a personalidade do ser com vida, mas merece proteção estatal como ente desprovido de possibilidade de vida, com proteção indireta, e direito a nome, sepultura e respeito à imagem (:214).

Os direitos citados surgem no constituir da noção de pessoa ao longo da história (Mauss 2003). Essa abordagem é ambivalente: por um lado, não considera o anencéfalo apto a adquirir personalidade, por outro, concede proteção e direitos próprios da pessoa como direito ao nome, ao sepultamento e a ter a imagem preservada.

\section{Direito à vida}

O direito à vida é ponto central para o posicionamento contrário à ação, mas é enfrentado também pelos favoráveis. A ministra Cármen Lúcia considera o direito à vida do nascituro e compara com o anencéfalo: "o direito à vida é garantia constitucional e, porque o nascituro tem a expectativa de vida, foram-lhe assegurados direitos presentes e futuros, esse com o nascimento com vida" (:209). Ela pondera que, se não há consenso quanto ao início da personalidade, verifica-se o fim da existência pela constatação da morte encefálica (:210).

No tocante ao direito à vida, há duas ideias diferentes no debate público sobre aborto: uma tese pressupõe que "fetos são criaturas com interesses próprios desde o princípio", "inclusive o direito de não serem mortos" (Dworkin 2003:12), o que representaria a perspectiva do direito à vida. De acordo com a segunda tese, "o aborto é errado em princípio, porque desconsidera e insulta o valor intrínseco, o caráter sagrado, de qualquer estágio ou forma de vida humana" (2003:13). 


\section{Dignidade}

A dignidade humana é um dos princípios invocados na ação e, para discuti-la, a ministra Cármen Lúcia cita o pensamento de Kant, em sua definição de liberdade que só é possível aos seres racionais e implica a possibilidade de fazer as próprias escolhas. Na concepção kantiana de dignidade humana, o ser humano não pode ser tratado como um meio para a obtenção de alguma coisa, mas considerado um fim em si mesmo (:223).

Fagot-Largeault, analisando os impasses das pesquisas com embriões humanos, afirma que: "O respeito, no sentido kantiano, destina-se ao agente moral, isto é, a um ser capaz de se autodeterminar, de se comportar segundo a representação que ele tem do imperativo moral" (2004:240). Continuando a analogia, nem o embrião, nem o feto anencefálico teriam autonomia moral.

\section{Direito de escolha}

Cármen Lúcia defende o direito de escolha: "Pela Constituição da República o direito à saúde abrange a proteção à maternidade. Ser mãe é dar à luz, permitir nascer uma nova vida, não deixar-se velar o ventre enquanto aguarda o dia do enterro do pequeno ser" (:235). Ressaltando o direito de prosseguir a gestação no caso da anencefalia ou de optar pela interrupção, a ministra afirma: "Quem não domina o seu corpo não é senhor de qualquer direito. Pelo que a escolha é direito da pessoa, não atribuição do Estado" (:236). Tal afirmativa sobre a escolha resume o princípio da autonomia, que é pilar da ideologia individualista moderna (Dumont 1997).

\section{Legislador positivo}

Uma indagação de natureza formal (sobre a correta condução do processo): se o STF, ao concordar com a ADPF, ultrapassaria suas prerrogativas de interpretar as leis segundo a Constituição, e acrescentaria uma nova exceção ao Código Penal, em razão da omissão normativa (omissão da lei) : não é punido o aborto em caso de diagnóstico de anencefalia.

Gilmar Mendes considera que, ao julgar o mérito da ADPF 54, o STF admitiu a possibilidade de atuar como legislador positivo, acrescentando um excludente de ilicitude ao crime de aborto (:302), ou seja, somando um permissivo em que o aborto não é punido.

Celso de Mello argumenta que a antecipação de parto não compreende a ideia de aborto. Nesse sentido, o tribunal deve acrescentar entre as modalidades de exclusão do crime de aborto uma terceira hipótese: 
antecipação terapêutica de parto de feto portador de anencefalia (:356). Essa sentença impediria a incriminação da mulher que opta pela interrupção da gestação.

\section{Direitos sexuais e reprodutivos e direitos humanos}

Celso de Mello confronta a "magnitude do direito à vida e a discussão em torno de sua titularidade" e os valores que se "fundam nos direitos sexuais e reprodutivos das mulheres": o direito da prática do aborto seguro, o de controlar a própria fecundidade e o de decidir sobre sua sexualidade. Tais direitos representam "projeção expressiva dos direitos humanos reconhecidos às mulheres" pelas conferências internacionais promovidas pela ONU (:318320). ${ }^{18}$ Ele cita resoluções de conferências internacionais voltadas a "eliminar preconceitos sexuais na administração da justiça" e erradicar conflitos que possam surgir entre direitos das mulheres e práticas tradicionais (:321).

\section{Posições contrárias à ADPF 54}

Se as grandes batalhas sobre aborto e eutanásia são realmente travadas em nome do valor intrínseco e cósmico da vida humana, [...] então essas batalhas têm uma natureza quase religiosa (Dworkin 2003:19).

Dois ministros votaram contra a ação: Ricardo Lewandowski e Cézar Peluso. As linhas de argumentação desses ministros são distintas, por isso, os votos serão analisados separadamente.

\section{Argumentação de Ricardo Lewandowski}

\section{Acusação de eugenia}

Lewandowski cita criminalistas que não consideram legítimo o aborto "eugenésico", quando a criança nasce com deformidade grave ou incurável, mas consideram punível. Refuta que na promulgação do Código Penal em 1940 e na reforma em 1984 não houvesse métodos de diagnóstico de patologias fetais. Defende que o Congresso Nacional, "intérprete último da vontade soberana do povo" (:241), com base nesse instrumental científico, poderia ter alterado a legislação para incluir o aborto eugênico.

O ministro usa o rótulo de acusação "aborto eugênico", acusação afastada por outros ministros ao alegarem a inviabilidade de vida extrauterina 
do anencéfalo, o que o diferenciaria do deficiente. Na audiência de instrução da ADPF 54, uma representante de entidade em defesa das pessoas portadoras de deficiência, contestou tal classificação, citando a Convenção das Nações Unidas para as Pessoas com Deficiência, porque deficiência pressuporia a presença de vida mesmo que na forma de expectativa de vida (Luna 2015). Segundo Diniz e Velez, "Confunde-se anencefalia e deficiência intencionalmente a fim de aproximar o debate sobre a interrupção da gestação do aborto eugênico", ou "como uma expressão da ignorância médica sobre o significado da anencefalia como uma malformação inviável e letal" (2007:30).

\section{Legislador positivo: o papel que não cabe ao STF}

De acordo com Lewandowski, não é possível fazer uma interpretação que afronte a "expressão literal da lei", e não se pode contrariar a vontade manifesta do legislador, nem de se substituir a ele (:244). O Supremo Tribunal Federal pode exercer apenas o papel de legislador negativo, tendo a função de retirar do ordenamento jurídico as normas incompatíveis com a Constituição.

Esse entendimento rejeita o papel de ampliar a intepretação da lei nesse caso específico: o Legislador positivo. Essa figura corresponde em termos sociológicos ao ativismo judicial, quando "profissionais do Judiciário identificam-se como responsáveis em aplicar os princípios estabelecidos pela Constituição Federal e questões de repercussão social e política [...] são decididas pelo Poder Judiciário e não pelo Congresso Nacional ou pelo Poder Executivo" (Coitinho Filho \& Rinaldi 2018:30). Esse papel foi admitido acima quando ministros favoráveis à ação defenderam a ampliação.

\section{Inviabilidade: outras doenças}

Lewandowski ressalva que, além de envolver o princípio fundamental de proteção à vida, uma decisão favorável ao abortamento de fetos anencefálicos permitiria tornar lícita a interrupção da gestação de qualquer embrião que tenha pouca ou nenhuma expectativa de vida intrauterina. Cita a CID $10^{19}$ da Organização Mundial de Saúde que arrola dezenas de patologias fetais sem chance de sobrevivência, além de outras referidas na audiência pública "acardia, agenesia renal, hipoplasia pulmonar, atrofia muscular espinhal, holoprosencefalia, ostogênese imperfeita letal, trissomia do cromossomo 13 e 15, trissomia do cromossomo 18" (:247). 
O ministro toca em ponto sensível: por que enfocar a anencefalia se há outras patologias incompatíveis com a vida? Esse argumento revela a importância do cérebro como órgão central para estabelecer a noção de pessoa: "uma concepção fisicalista que relaciona cérebro e indivíduo", traço central na concepção de pessoa moderna (Azize 2010). Esse aspecto está relacionado ao argumento da impossibilidade de vida de relação, o que se choca com a condição de pessoa. Por outro lado, a enumeração de outras patologias invoca a tese da ladeira escorregadia (Diniz 2014), que pressupõe uma abertura geral para qualquer caso.

\section{Direitos do nascituro}

O ponto central para o ministro são os direitos do nascituro. Lewandowski ressalta a existência de outras legislações que protegem a vida intrauterina, com destaque para o artigo 2 do Código Civil: "a lei põe a salvo, desde a concepção, os direitos do nascituro" (:248). Essa lei e outras legislações garantiriam proteção de fetos que podem ter a vida encurtada por serem portadores de patologias.

O ministro considera os fetos de modo geral e o anencefálico em particular como sujeito titular de direitos (cf. Dworkin supra)

\section{Deficiência física: graus de anencefalia}

Para sustentar a analogia com a discriminação das pessoas portadoras de deficiência física, o ministro fala em graus de anencefalia. Segundo Lewandowski, a ciência demonstra haver

Vários graus de anencefalia, desde uma anencefalia total, completa, em que há inviabilidade plena de sobrevida do feto, até uma anencefalia menos grave, que permite até uma vida, por um certo período de tempo, que não é completamente vegetativa $(: 370)$.

O argumento sobre graus de anencefalia, fundamentado na condição biológica, remete ao conceito de biossocialidade de Rabinow (1999) referente a termos de identidade, através dos quais os sujeitos se organizam na sociedade contemporânea com o advento da nova genética. 


\section{Argumentação de Cézar Peluso}

Os votos contrários à ação concordam com a impossibilidade de o Supremo Tribunal Federal assumir o papel de legislador positivo. O voto de Peluso, então presidente do STF, tem uma linha argumentativa distinta, evocando a "retórica emocional e estridente" (Dworkin 2003:26-27) do ativismo antiaborto.

\section{Presença de vida no anencéfalo}

Ele cita o próprio voto na ADI 3510. Afirma que a noção de vida não é uma criação da ciência jurídica, mas uma "realidade pré-jurídica" de que se apropria o Direito (:378). Refuta ser possível "pensar o ser humano como entidade que só mereça qualificação jurídico-normativa de ser vivo, quando seja capaz de pleno desenvolvimento orgânico e social, de consciência e de interação" (:378). Sustenta que todo anencéfalo é dotado dessa capacidade de movimento autógeno (por si mesmo) vinculada ao processo da vida, a não ser que já tenha morrido.

Essa posição se contrapõe às de Rosa Weber e Joaquim Barbosa, que consideraram essencial o papel constitutivo da ciência jurídica em estabelecer conceitos e fatos (semelhante à perspectiva do construcionismo social). Já, no entender de Peluso, a base biológica é precedente, pensamento que se dá conforme a cosmologia ocidental moderna, quando a natureza é considerada a base da realidade, e o corpo biológico "a-histórico" se torna fundamento de prescrições da ordem social (Laqueur 1992).

\section{Questionamento da analogia com a morte encefálica}

Peluso julga insuficiente a analogia entre morte encefálica e o início da vida a partir dos seguintes argumentos: 1 . A morte encefálica caracteriza-se por ser "uma situação de prognóstico, de uma irreversibilidade em que não há respiração espontânea" (:380), o que não é o caso do anencéfalo; 2. Avalia que a audiência pública produziu resultados contraditórios acerca da existência de atividade cerebral no anencéfalo; 3. Refuta que o feto acometido de anencefalia não tenha encéfalo; 4. A morte encefálica representa a interrupção irreversível do ciclo vital que chega ao fim, enquanto a anencefalia integra o processo contínuo e progressivo chamado vida, por isso, sua evolução em relação à morte não pode ser abreviada; 5. Insiste na inconsistência da analogia com a morte cerebral, mas reconhece que o fundamento jurídico de aproveitar os órgãos no caso de morte encefálica 
é o mesmo que autoriza o aborto terapêutico, pois, em ambas as situações, leva-se em conta o ato necessário para salvar a vida de terceiros, sendo estes o receptor de órgãos e a gestante (: 381-382). Esse ponto é o cerne de sua argumentação.

Peluso rebate a invocação dos princípios da autonomia da vontade, da liberdade pessoal e da legalidade como fatores de legitimação do aborto de anencéfalo, e considera crime toda interrupção dolosa do curso da vida intrauterina (:382). Para configurar o aborto como crime, basta a eliminação da vida, abstraída de especulação quanto à viabilidade extrauterina, conduta proibida por lei. Não se resguarda a autonomia da vontade quando se volta "ao indisfarçável cometimento de um crime" (:383). Não caberiam os excludentes de punibilidade do aborto. ${ }^{20}$

\section{Dignidade da vida intrauterina: aborto como assassinato}

Equiparar ao assassinato é ponto-chave da retórica do ativismo antiaborto. Peluso compara o aborto de feto anencefálico e o assassinato de bebês com anencefalia recém-nascidos, dizendo que diferem apenas no "momento de execução". Afirma que, sob a Constituição, formas de vida intrauterina e extrauterina teriam o mesmo nível de dignidade, e que ninguém aceitaria matar um bebê anencéfalo nascido "com a finalidade de poupar a mãe à carga de frustração, sofrimento, tortura psicológica" (:387) . Peluso rebate o argumento da ADPF 54, afirmando que a dignidade da vida intrauterina está em jogo (:387s). Refuta que o direito à vida seja "suscetível de graduações axiológicas" (:389): direito à vida absoluto.

Quando Peluso atribui a mesma dignidade à vida intrauterina e à vida extrauterina, considerando absoluto o direito à vida, ele parece fechar a possibilidade do aborto legal, que seria considerado "execução". Contudo o ministro aceita as hipóteses em que não se pune o aborto no caso do estupro e para salvar a vida da mãe. Ele enfatiza que qualquer gestação incorre em risco à saúde. Quanto ao estupro, sua ênfase é que a autonomia da mulher foi ferida com a violência sexual, mas ele destrói todos os argumentos fundamentados nos direitos sexuais e reprodutivos, questionando a autonomia da mulher como um valor inferior à dignidade da vida do anencéfalo.

O pensamento de Peluso explicita o princípio da hierarquia de Dumont (1997), sendo a gestante de anencéfalo englobada pelo feto considerado um sujeito. A crítica feminista a tal posição afirma que, do ponto de vista do "controle patrimonial dos corpos", a mulher não é uma pessoa (Rostagnol 2008), ponto sugerido nos votos de Peluso e Lewandowski. 
Nessa perspectiva, as gestantes de anencéfalos são menos merecedoras de direitos que o feto inviável, como na comparação entre sujeitos mais e menos humanos (Fonseca \& Cardarello 1999).

\section{Comparação com eutanásia}

Peluso considera que a curta potencialidade da vida não representa razão válida para impedir sua continuidade. Compara o aborto de anencéfalo e a eutanásia: argumenta que nesses dois casos se quer autorização jurídica para a prática de um crime.

Tal comparação, frequente na retórica antiaborto, revela questões centrais comuns ao debate acerca da eutanásia: a crença na "manutenção do estado vital como único valor atribuído à vida" (Menezes \& Ventura, 2013:217), entendimento estreito que não admite espaço para liberdades individuais nem pluralismo moral, em discurso que culpabiliza os atores sociais, segundo Peluso, por "impertinentes ideias de liberdade pessoal" (:406).

\section{Impossibilidade de certeza do diagnóstico}

O ministro Peluso alega a impossibilidade de certeza do diagnóstico de anencefalia. Cita o exemplo de Marcela de Jesus, cujo diagnóstico foi controverso mesmo após o nascimento. Contudo, seria contrário ao aborto até havendo certeza: "ainda que a técnica evoluísse a ponto de discernir claramente os casos de verdadeira anencefalia, a eliminação daquele feto não seria compatível com o Direito" (:402).

Tortura: sofrimento não é degradante

Peluso rebate os argumentos que obrigar uma mulher a manter contra sua vontade a gravidez de anencéfalo até o fim seria comparável à tortura. Segundo ele, o método proposto para encurtar o sofrimento tem impedimentos legais por constituir crime de aborto e constitucionais (direito à vida e à dignidade humana do feto) (:403-404). Afirma que o sofrimento no caso não é infligido propositadamente. Acusa a ação de culpar o Estado por dramas originados da conjugação de ato livre e do acaso biológico (:404). O ministro, ao identificar a origem da anencefalia no acaso, nega haver injustiça. Defende que: "O sofrimento em si não é alguma coisa que degrade a dignidade humana; é elemento inerente à vida humana" (:404). O sistema jurídico repudia apenas os atos injustos que causem o sofrimento. 
Apenas o sofrimento vindo da prática de um ato ilegal não pode ser admitido pela ordem normativa. Diniz e Velez contestam: "Em um ordenamento jurídico laico e plural, não importa se há origem para essa injustiça ou se ela é imputada à loteria da natureza", e alertam para "mecanismos sociais de proteção ou de abandono desta mulher" (2007:31). A tese de Peluso, em sua indiferença à dor da gestante e da família, ilustra o Estado produtor de sofrimento social (Victora 2011).

\section{Liberdade de escolha}

Peluso refuta também o princípio da liberdade de escolha, pois a solução (o aborto) apoia-se em:

Impertinentes ideias de liberdade pessoal, inexistente quando se cuida da tipificação de crime, e de tortura, onde não há sofrimento injusto nem intencional, reflete apenas uma atitude individualista e egocêntrica, enquanto sugere prática cômoda de que se vale a gestante para se livrar do sofrimento e da angústia, sobrepondo ao sentido ético de respeito (:406).

Afirma que os males de que a mãe padece não foram originados de um terceiro, como na gravidez decorrente de estupro, nem ameaçam a sua vida, nem degradam a dignidade humana (:407).

A ênfase total no feto em detrimento da gestante, cujo sofrimento não degradaria sua dignidade, segundo o ministro, reduz a mulher a suporte para desenvolvimento fetal.

Essa posição de Peluso ignora a mulher e a destitui de dignidade.

\section{Ponderação a favor do anencéfalo}

Peluso também apela para o esquema de ponderação de bens, mas para a defesa do anencéfalo contra o direito de escolha da gestante:

A vida humana, hospedada na carne frágil de feto imperfeito, não pode, a despeito da fortuita imperfeição que lhe não subtrai a dignidade jurídica imanente, ser destruída a fórceps para satisfazer sentimento, quase sempre transitório, de frustração e de insuportabilidade personalíssima de uma dor ainda que legítima (:407). 
Estupro: sem analogia

Peluso passa ao caso de estupro: neste a concepção decorre de ato delituoso de outrem, caso em que repugna à mulher manter a gravidez como consequência "inevitável, de violência odiosa e sobremodo injusta" (:408, ênfases originais). Culpa pela anencefalia pode ser atribuída ao acaso, à natureza, à genética. Isso não torna esse acontecimento trágico injusto do ponto de vista da lei. No caso do estupro, a gravidez se origina de ato ilícito de força física, enquanto a gravidez de anencéfalo é livre em sua origem (:408-409).

Assim o ministro atribui à natureza a anomalia fetal, por isso seria impossível imputar a injustiça no surgimento da malformação. Isso justificaria omitir-se de minorar o sofrimento da mulher, prezando a dignidade da pessoa fetal acima da gestante. Vê-se aqui de novo um agente do Estado promovendo o sofrimento social (Victora 2011), desta vez na falta total de empatia com o sofrimento das gestantes.

\section{Saúde}

Peluso refuta o argumento de que a gestação de anencéfalo seria perigosa para a saúde da mãe, caso compreendido na hipótese de aborto terapêutico. Refuta assim o direito à saúde, posto que qualquer gravidez implica risco teórico à saúde da gestante, mas nem por isso a lei autoriza a prática de aborto (:410s).

\section{Contra o legislador positivo}

Segundo o ministro, a corte não pode se responsabilizar por uma inovação normativa que a arguente (autora da ADPF) e os "adeptos" de sua tese sabem que talvez não fosse adotada pelo Congresso Nacional "como intérprete autorizado" do povo (:413).

Aqui se explicita a crítica do ministro ao ativismo judicial.

\section{Dignidade do concepto}

Peluso considera insustentável deduzir do rol de direitos sexuais e reprodutivos "o reconhecimento da existência de poder absoluto de eliminar a vida intrauterina" (:414s), e aponta como resultado "a completa reificação do concepto, transformado em mero objeto disponível, sem nenhuma dignidade jurídica" (:415). 
Segundo Diniz e Velez (2007), a posição do ministro se caracteriza pela passionalidade jurídica e pela metafísica cristã e condensa a argumentação moral contrária a reconhecer a interrupção da gestação em caso de anencefalia como direito reprodutivo no país. A sustentação é que o aborto seria o atentado contra uma vida em potencial, tese fundamentada em pressupostos morais sobre a sacralidade da vida humana a ser protegida pelo Estado. O feto é aqui um sujeito de direitos, nas palavras de Dworkin (2003).

Cabe reproduzir um trecho da dinâmica do debate após encerrada a votação. O ministro Carlos Ayres Britto elogiou a fundamentação do voto do ministro Peluso por ser coerente com as suas crenças.

Vossa Excelência acha que nascemos para morrer. Eu acho que nascemos para o espetáculo da vida e, por isso, eu permaneço entendendo que não devemos, jamais, a pretexto de defender quem sofre, no fundo, amar o sofrimento (:417).

Os votos dos juízes Lewandowski e Peluso contestam o argumento feminista do "direito de dispor do próprio corpo". Assinala-se a semelhança desse posicionamento com a posição da Igreja Católica sobre aborto que considera que biologicamente o filho não é parte do corpo da mãe, mas sim seu hóspede. ${ }^{21}$ A defesa da vida, argumento identificado por Sales (2015), também vai na direção de individualizar esse feto, tratando-o como pessoa. Strathern reconhece que a biotecnologia provê novas maneiras de conceitualizar a individualidade do feto, mas observa que a gestante é um caso paradigmático para se pensar o parentesco como pessoas sendo partes de pessoas (Strathern 2005:29). Nesse sentido, a autora apresenta uma interpretação diferente acerca da relação mãe e feto: a mulher grávida constitui um nexo de relações (nexus of relations). Assim, o relacionamento entre mãe e feto não é o de parceiros iguais. A separabilidade do corpo materno é a base da interdependência de gestante e feto: mãe e feto são tanto separáveis como partes um do outro (Strathern 2005:30).

Com respeito à posição antiaborto representada pelos ministros Lewandowski e Peluso, segundo Dworkin, tal posição conservadora "tem por base uma concepção de santidade da vida que dá absoluta prioridade ao investimento divino ou natural na vida" (2003:131). A vida aqui aparece como valor holístico, apontando para a totalidade e não para o elemento, ou para o indivíduo (Duarte 2004). 


\section{Considerações finais}

Em debate no julgamento está se o anencéfalo tem a condição de pessoa humana na acepção delineada por Mauss (2003), ao falar da construção histórica da noção de pessoa e do eu, ou se a gestante deve ter sua condição de pessoa, sujeito de direitos, inclusive o da dignidade, apequenada pelo entendimento da maternidade como suporte para o desenvolvimento fetal. Tal visão foi explicitada nas ironias do ministro Peluso contra os direitos de autonomia da mulher, negando qualquer importância ao seu sofrimento.

Peluso e Lewandowski assumem a posição em "defesa da vida" identificada na audiência pública que precedeu o julgamento (Sales 2015). Ambos ilustram a análise de Víctora sobre sofrimento coletivo, tanto em contestar sofrimento na dimensão coletiva das diversas mulheres que o experimentam como pela omissão das autoridades, o que repercute nas políticas públicas, e nas interpretações da lei, acrescento.

Este artigo, ao identificar e analisar a argumentação emitida pelos ministros do STF no julgamento da ADPF 54, com respeito à possibilidade de antecipação de parto de anencéfalo, apresenta questões específicas distintas da análise da audiência pública da ADI $3510^{22}$ apenas com cientistas, e da própria audiência da ADPF 54 que, além de cientistas, era composta também de representantes de grupos religiosos e da sociedade civil (Luna 2015). Nestas, não havia juristas. Ao se debruçar sobre a construção dos argumentos por juristas, este artigo pode traçar paralelos com a análise anterior, mas também contrastes. Percebeu-se por parte de vários ministros a necessidade de diferenciar a noção de vida como definida pela ciência e aquela que pode ser empregada no âmbito jurídico. Embora tópicos pudessem ser classificados com ênfase maior em descrições biológicas, ou em questões muito específicas de saúde, a dimensão social se ressalta para assegurar a leitura pelo prisma do Direito, como na diferença entre a concepção biológica e a jurídica de vida.

O diagnóstico de anencefalia durante uma gestação reconfigura as expectativas em relação à gravidez, por conta da inviabilidade do feto. Este, na tipologia proposta por Boltanski (2004), deixa de ser um feto autêntico, destinado ao nascimento e considerado como um sujeito, para se tornar um feto tumoral, que é destinado ao nada.

Laqueur, em seu livro Making sex, afirma que, com o Iluminismo, a natureza se torna o fundamento epistêmico para prescrições da ordem social (1992), como se houvesse um corpo biológico a-histórico. Examinando os votos de ministros do STF no julgamento da ADPF 54, julgamento no qual estava em jogo a possibilidade de mulheres terem autonomia para decidir continuar ou não uma gestação com o diagnóstico de anencefalia, 
percebe-se a força dos fatores biológicos. O peso está na definição do que é anencefalia, a viabilidade ou não do feto e os riscos físicos para a gestante. Não por acaso, os ministros favoráveis à ação repetiram o parâmetro de morte encefálica para se pronunciarem em favor da autonomia da gestante decidir (princípio jurídico da liberdade) e da preservação de sua saúde (um direito constitucional). Por outro lado, não teria sido o critério da morte encefálica se este não estivesse reconhecido em um diploma legal, a lei de transplantes. Os ministros se esforçam para mostrar a inexistência de mera subordinação do Direito à Ciência, ponto que o voto de Rosa Weber levou à exaustão, mas prevalece nas decisões uma lógica jurídica não atrelada à lógica biomédica. São contrapostos dois fundamentos, como exemplifica a feliz expressão do ministro Joaquim Barbosa: o feto anencefálico pode ser biologicamente vivo, mas juridicamente morto.

Ao contrapor a autonomia da mulher e seu direito à saúde ao direito à vida do nascituro, um feto anencefálico, ambas as posições são construídas com base na configuração individualista de valores característica do Ocidente moderno (Dumont 1997). Os dois lados falam em nome da dignidade humana, seja a do feto, visto como um ser indefeso e deficiente, que teria direito à vida, seja a da mulher, um ser formado que deve ter garantidos sua autonomia reprodutiva e direito à saúde física e psíquica contra o Estado, o qual a obrigaria a prosseguir uma gestação inviável. Usando o raciocínio jurídico da ponderação, quando há princípios em disputa, a maioria dos ministros considerou que prevaleceria como bem maior a proteção da mulher. Para tanto, a maioria sopesou a inviabilidade do feto, mas vários evocaram suas características que o afastariam da humanidade, em particular a total incapacidade de adquirir consciência. Isso responde à pergunta do ministro Lewandowski, que questionou por que considerar apenas a anencefalia, quando há diversas anomalias incompatíveis com a vida. O anencéfalo não tem consciência nem racionalidade em grau mínimo (daí a acusação de eugenia), mas tem expectativa de vida praticamente nula, salvo casos excepcionais.

Se o direito do feto à vida remete à sacralidade da vida humana (Dworkin 2003), reconhecendo que a vida humana tem valor intrínseco, a luta pelo direito do feto bem como pelos interesses da mulher mostra como na modernidade o indivíduo é sagrado e o valor supremo, ponto revelado por Durkheim quando afirmou que o individualismo seria a religião da humanidade (1970). O valor da vida não é mero princípio biológico, mas aponta para dimensões holistas presentes na configuração individualista de valores. Através de seus votos, os ministros definem o que é sagrado (Durkheim 1989) na sociedade brasileira no julgamento desse caso. 
A maioria dos votos compreendeu que obrigar uma mulher contra a vontade a manter até o final a gestação de um feto inviável insultaria a dignidade da pessoa humana, outro valor sagrado. Nesse sentido, a maioria dos ministros foi sensível ao sofrimento das mulheres e de suas famílias, enquanto os dois contrários, ao defenderem a vida fetal como valor absoluto, agravam o sofrimento social (Víctora 2011) das gestantes que querem interromper essa gestação inviável. Estendo à análise da controvérsia sobre o aborto pontos do debate sobre a eutanásia: sofrimento e dignidade como categorias fundamentais, a garantia do direito de autonomia como mecanismo para evitar o sofrimento humano e a necessidade de refletir sobre os modos possíveis de compreensão e respeito ao valor da vida (Menezes \& Ventura 2013).

Por fim, a despeito de concluir que o julgamento se dá enquanto encenação da configuração individualista de valores, verifica-se que a dimensão holista, referente à totalidade, está presente na orientação para a vida (Duarte 2004). Além disso o próprio princípio da hierarquia é usado nos raciocínios estabelecidos na prática da ciência jurídica. A hierarquia implica a adoção de um valor: a relação hierárquica implica a orientação para o conjunto em vez de para o elemento (Dumont 1997). Conforme argumentado pela ministra Rosa Weber, o princípio da proporcionalidade, aplicado à antecipação de parto de anencéfalo, entende que privilegiar a vida de um feto inviável, independentemente de considerações sobre os sentimentos e as decisões da gestante, seria desrespeitar ao extremo a condição de sujeito dessa mulher e sua dignidade, o que implicaria privilegiar o elemento (feto anencefálico inviável) sobre o conjunto (díade mãe-feto, ou o nexo de relações, segundo Strathern 2005 23 ). O princípio da ponderação se assemelha ao princípio hierárquico: quando há valores em disputa, no caso, o direito à vida do anencéfalo, e o direito à dignidade e à autodeterminação da mulher gestante, o ministro Peluso, representando a posição pró-vida e antiaborto, hierarquiza a favor do feto, enquanto a maioria dos ministros prioriza a mulher. Cada posição mostra o que é sagrado para os ministros que votam: a vida do anencéfalo para uns, a vida da mulher e sua dignidade e autonomia para a maioria.

Passados nove anos do julgamento da ADPF 54, a decisão do STF se mantém, contudo, esse resultado estimulou iniciativas no Legislativo (Câmara e Senado) para sustar seus efeitos, além de a anencefalia ter sido incluída em diversos projetos de lei antiaborto, o que indica que a disputa não cessou especialmente por parte de setores conservadores, marcadamente religiosos (católicos carismáticos, evangélicos e espíritas), enquanto os setores pró-escolha deixaram de se mobilizar no Legislativo no tocante à anencefalia. 
Recebido em 09 de agosto de 2019

Aprovado em 26 de agosto de 2021

Naara Luna é antropóloga com doutorado no PPGAS, Museu Nacional, UFRJ. Ela atua como professor associado na UFRRJ, onde é docente do PPGCS, e no DCS. É autora do livro Provetas e clones: uma antropologia das novas tecnologias reprodutivas e de diversos artigos versando sobre novas tecnologias reprodutivas, o debate público sobre aborto e diversidade sexual, estatuto do feto e do embrião, aspectos culturais das pesquisas com células-tronco, natureza e cultura e a interface desses temas com o Direito e a religião. É pesquisadora CNPq com bolsa de produtividade nível 2. Integra a comissão Laicidade e Democracia da ABA e o GT Religión, neoliberalismo y pos/decolonialidad da CLACSO.

O artigo foi desenvolvido com apoio do CNPq no âmbito do projeto: "Aborto e diversidade sexual no debate público sobre direitos humanos no Brasil: Estatuto do Nascituro, 'ideologia de gênero' e cura gay na interface Natureza/Cultura, Direito e Religião".

https://orcid.org/0000-0002-6137-7405

E-mail: naaraluna2015@gmail.com

\section{Notas}

1 Foi o caso de Gabriela, cuja solicitação judicial de interromper a gravidez foi acolhida pela promotora, mas negada pelo juiz e pelo tribunal, que emitiu um habeas corpus em favor do feto anencefálico, motivando Débora Diniz a escrever um habeas corpus em favor da gestante (Diniz 2014).

2 Segundo o Dicionário Jurídico: "uma ADPF "tem por objeto evitar ou reparar lesão a preceito fundamental decorrente da Constituição, resultante de qualquer ato (ou omissão) do Poder Público". Disponível em: https://www.direitonet.com.br/ dicionario/exibir/1130/Arguicao-de-Descumprimento-de-Preceito-FundamentalADPF. Acesso em 02/04/2020.

3 Autorizar o aborto em caso de anencefalia seria um ato eugênico do Estado brasileiro na perspectiva dos questionadores da ação, o que, segundo Diniz, seria "o principal argumento religioso contra a ação nos anos finais da tramitação no STF" (:165). Mediante análise das audiências públicas, é possível dizer que era um argumento usado por religiosos, mas não um argumento religioso (Luna 2013, 2015). 
4 Segundo o artigo "A Constituição e o Supremo", podem solicitar a ADPF: o presidente da República, mesa do Senado, mesa da Câmara dos Deputados, mesa da Assembleia Legislativa ou da Câmara Legislativa do DF, governador do estado ou do Distrito Federal, partido político com representação no Congresso Nacional. Disponível em: http://www.stf.jus.br/portal/constituicao/artigoBd.asp?item=1106 Acesso em 02/04/2020.

5 A expressão "antecipação terapêutica de parto" e a alegação de não ser aborto constituem um artifício retórico na batalha discursiva para aprovar a legalidade do procedimento de interromper a gravidez sem criar um novo excludente de ilicitude fora da lei vigente, o que poderia invalidar a ação logo de início. Trata-se de uma etapa na controvérsia pública sobre aborto, tópico que será definido adiante.

6 O acórdão do julgamento em seu inteiro teor publicado no site do STF tem 433 páginas. Para evitar a excessiva extensão do artigo que a cópia literal implicaria, os argumentos serão resumidos, tentando manter a proximidade com o vocabulário usado. Para fins de conferência, as páginas das citações serão indicadas.

7 Marcela de Jesus teve diagnóstico de anencefalia durante o pré-natal. Sua sobrevida excepcional de um ano e oito meses levou diversos especialistas a questionar esse diagnóstico, ainda na audiência pública da ADPF 54 em 2008, quando foi mencionada para questionar a antecipação terapêutica de parto, defendendo que a anencefalia não implicaria letalidade total na vida extrauterina, ou como um erro de diagnóstico por parte dos que eram favoráveis à tese da ADPF 54. A menina foi citada nominalmente poucas vezes no acórdão do julgamento: além do relator, ela é mencionada por Rosa Weber repetindo o voto do relator como erro de diagnóstico e várias vezes por Cézar Peluso como contraponto à certeza de diagnóstico. É interessante que uma figura tão central no debate em momento anterior, no julgamento é deixada de lado em função da posição da maioria de ministros favoráveis à tese da ADPF 54 .

8 Baseado na Resolução CMF 1480/97 que autoriza a doação dos órgãos de anencéfalo,

9 Isso significa que lei protege ou tutela elementos fundamentais para a vida em sociedade, os chamados bens jurídicos (Zoghbi 2013), no caso em questão, a vida do feto anencefálico, e que o relator não considera justificada essa proteção.

10 Entre os riscos físicos são citados: aumento de morbidade e risco, apresentação fetal anômala que obriga ao parto cesáreo, poli-hidrâmnio (aumento do líquido amniótico) e, em função disso, hipertensão, parto prematuro, hemorragia pós-parto e prolapso de cordão, diabetes, gravidez prolongada, hipotonia do útero pós-parto e hemorragia.

11 "Respectivamente, nos artigos $1^{\circ}$, inciso III, $5^{\circ}$, cabeça e incisos II, III e X, e $6^{\circ}$, cabeça, da Carta da República" (:69)

12 Segundo a ministra, é crime por definição praticado apenas pela mãe no período puerperal (:105). 
13 "Religiosos" em suas palavras, mencionando apenas países de cultura cristã: Itália, Alemanha, Espanha e Estados Unidos

14 Não encontrei na cobertura da imprensa sobre o julgamento nenhum comentário polemizando essa colocação do ministro, provavelmente por não ter assumido a posição contrária ao direito de escolha em caso de aborto.

15 Antijurídico é o que contraria a lei penal, viola bens jurídicos protegidos pela lei: aqui negar à mulher o seu direito seria antijurídico.

16 Sintetizo aqui a análise de Weber no capítulo sobre Sociologia do Direito (1998).

17 Mauss sintetiza como se constitui historicamente essa categoria de pensamento em sua conclusão: "de uma simples mascarada, à mascara; de um personagem a uma pessoa, a um nome, a um indivíduo, deste a um ser com valor metafisico e moral; de uma consciência moral a um ser sagrado; deste a uma forma fundamental de pensamento e ação; foi assim que o percurso se realizou" (2003:397).

18 O ministro cita a Conferência de Viena sobre Direitos Humanos, de 1993, a Conferência de Cairo sobre População e Desenvolvimento, de 1994, e a IV Conferência Mundial sobre a Mulher, de 1995, realizada em Pequim (:318). Cita a Declaração e o Programa de Ação de Viena adotados pela Conferência Mundial sobre Direitos Humanos, promovida pela ONU, que reconhece que os direitos das mulheres são inalienáveis e que "constituem parte integral e indivisível dos direitos humanos universais" (:319-320).

19 Classificação Estatística Internacional de Doenças e Problemas Relacionados à Saúde, Décima Revisão.

20 Exceções em que lei não pune o aborto: estupro ou risco de vida da mãe.

21 Essa expressão foi obtida do manual Keys to bioethics, adotado pela Igreja Católica como material para participantes da Jornada Mundial da Juventude em 2013.

22 Referente ao uso de embriões humanos restantes de reprodução assistida em pesquisa para obtenção de linhagens de células-tronco.

23 Embora a biotecnologia apresente novas formas de conceber a individualidade do feto, argumento apontado por Strathern acima, a autora recorda que essa percepção não deslocou no contexto ocidental a doutrina jurídica de que o feto não tem personalidade legal. Considerando que o feto depende do corpo materno para sua sobrevivência, mas que o próprio corpo da mulher é modificado pela gravidez, em vez de afirmar a individualidade desses entes, segundo Strathern, a gestante e o feto são tanto separáveis como partes um do outro, por isso a imagem do nexo de relações (2005:29-30). 


\section{Referências bibliográficas}

AZIZE, Rogerio Lopes. 2010. "O cérebro como órgão pessoal: uma antropologia de discursos neurocientíficos". Trabalho, educação e saúde, 8 (3):563-574

BOLTANSKI, Luc. 2004. La condition foetale: une sociologie de l'engendrement et de l'avortement. Paris: Gallimard.

COITINHO FILHO, Ricardo Andrade \& RINALDI, Alessandra de Andrade. 2018. "O Supremo Tribunal Federal e a 'união homoafetiva': onde os direitos e as moralidades se cruzam". Civitas, 18 (1):25-39.

DINIZ, Debora. 2014. "A arquitetura de uma ação em três atos: anencefalia no STF". DIREITO.UNB, v. 1:161-183.

DINIZ, Debora \& GONZÁLEZ VÉLEZ, Ana Cristina. 2007. "Aborto e Razão Pública: o desafio da anencefalia no Brasil". Número Especial Gênero, Religião e Políticas Públicas. Mandrágora, 13:22-32.

. 2008. "Aborto na Suprema Corte: o caso da anencefalia no Brasil". Revista Estudos Feministas, 16 (2):647-652.

DUARTE, Luiz Fernando D. 1996. "Distanciamento, reflexividade e interiorização da pessoa no Ocidente". Mana, 2 (2):163-176. . 2004. "A pulsão romântica e as ciências humanas no Ocidente". Revista Brasileira de Ciências Sociais, 19 (55):5-18.

DUMONT, Louis. 1997 [1967]. Homo hierarchicus: o sistema de castas e suas implicações. São Paulo: EDUSP.

DURKHEIM, Émile. 1973 [1895]. As regras do método sociológico e outros textos. Coleção Os Pensadores. Vol. XXXIII. São Paulo: Abril.
. 1989. [1912] As formas elementares da Vida Religiosa. São Paulo: Paulinas. . 1970. [1898] "L'individualisme et les intellectuels". In: _ , La science sociale et l'action. Paris: Presses Universitaires de France. pp. 261-278.

DWORKIN, Ronald. 2003. Domínio da vida: aborto, eutanásia e liberdades individuais. São Paulo: Martins Fontes.

FERNANDES, Maíra Costa. 2007. "Interrupção de gravidez de feto anencefálico: uma análise constitucional". In: D. Sarmento \& F. Piovesan (orgs.), Nos limites da vida: aborto, clonagem humana, eutanásia sob a perspectiva dos direitos humanos. Rio de Janeiro: Lumen Juris. pp. 111-158.

FONSECA, Claudia \& CARDARELLO, Andrea. 1999. "Direitos dos mais e menos humanos". Horizontes Antropológicos, 5 (10):83-121.

GIUMBELLI, Emerson. 2002. "Para além do 'trabalho de campo': reflexões supostamente malinowskianas". Revista Brasileira de Ciências Sociais, 17 (48):91-107.

JÚDICE, Mônica Pimenta. 2007. "Robert Alexy e a sua teoria sobre os princípios e regras". Revista Consultor Jurídico, 2 de março de 2007. Disponível em: < https://www.conjur.com. br/2007-mar-02/robert alexy teoria principios regras?pagina $=2>$ Acesso em 07/09/2020.

LAQUEUR, Thomas. 1992. Making sex: body and gender from the greeks to Freud. Cambridge: Harvard University Press. 
LUNA, Naara. 2013. "O direito à vida no contexto do aborto e da pesquisa com células-tronco embrionárias: disputas de agentes e valores religiosos em um Estado laico". Religião \& Sociedade, 33 (1):71-97.

. 2015. "From abortion to embryonic stem cell research: Biossociality and the constitution of subjects in the debate over human rights". Vibrant: Virtual Brazilian Anthropology, 12 (1):167-203.

MARIANO, Ricardo. 2011. "Laicidade à brasileira: católicos, pentecostais e laicos em disputa na esfera pública". Civitas: Revista de Ciências Sociais (Impresso), 11 (2):238-258.

MAUSS, Marcel. 2003 [1938]. "Uma categoria do espírito humano: a noção de pessoa, a de 'eu'". In:

Sociologia e antropologia. São Paulo: Cosac \& Naify. pp. 367-397.

MENEZES, Rachel Aisengart \& VENTURA, Miriam. 2013. "Ortotanásia, sofrimento e dignidade: entre valores morais, medicina e direito". Revista Brasileira de Ciências Sociais, 28 (81):213-229.

MUZZOPAPPA, Eva \& VILLALTA, Carla. 2011. "Los documentos como campo. Reflexiones teórico-metodológicas sobre un enfoque etnográfico de archivos y documentos estatales". Revista Colombiana de Antropología, 47(1):13-42.

PENNA, Maria Lúcia Fernandes. 2005. "Anencefalia e morte cerebral (neurológica)". Physis, 15 (1):95-106.
RABINOW, Paul. 1999. "Artificialidade e iluminismo: da sociobiologia à biossocialidade". In: , Antropologia da razão: ensaios de Paul Rabinow. Rio de Janeiro: Relume Dumará. pp. 135-157.

ROSTAGNOL, Susana. 2008. "El conflicto mujer-embrión en debate parlamentario sobre el aborto". Estudos Feministas, 16 (2):667-674.

SALES, Lilian. 2015. "'Em defesa da vida humana': moralidades em disputa em duas audiências públicas no STF". Religião e Sociedade, 35 (2):143-164. STRATHERN, Marilyn. 2005. Kinship, law and the unexpected: relatives are always a surprise. Cambridge: Cambridge University Press.

VÍCTORA, Ceres. 2011. "Sofrimento social e a corporificação do mundo: contribuições a partir da Antropologia". RECIIS: Revista Eletrônica de Comunicação, Informação e Inovação em Saúde, 5 (4):3-13.

WALDBY, Catherine. 2002. "Stem cells, tissue cultures and the production of biovalue". Health, 6 (3):305-323.

WALDBY, Catherine \& SQUIER, Susan. 2003. Ontogeny, Ontology, and Phylogeny: Embryonic Life and Stem Cell Technologies. Configurations, v. 11, n. 1:27-46.

WEBER, Max. 1998 [1922]. Economía y Sociedad. México: Fondo de Cultura Económica.

ZOGHBI, Sérgio. 2013. "Tutela penal dos bens jurídicos individuais". Jusbrasil. Disponível em: https://sergiozoghbi. jusbrasil.com.br/artigos/111903746/ tutela-penal-dos-bens-juridicos-individuais?ref=home. Acesso em 19/10/2020. 


\section{Fontes}

BRASIL. 2012. Supremo Tribunal Federal. Acórdão Inteiro Teor da Arguição de Descumprimento de Preceito Fundamental (ADPF) 54.

BRASIL. 2004. Supremo Tribunal Federal. Confederação Nacional de Trabalhadores da Saúde. Petição inicial da Arguição de Descumprimento de Preceito Fundamental (ADPF) 54.

Keys to bioethics - JMJ Rio 2013: Manual de Bioética "Chaves para a bioética". 2013. Brasilia: Fondation Jerôme Lejeune/ Comissão Nacional da Pastoral Familiar. 
O DIREITO AO ABORTO EM CASO

DE ANENCEFALIA: UMA ANÁLISE

ANTROPOLÓGICA DO JULGAMENTO

DA ADPF 54 PELO SUPREMO

TRIBUNAL FEDERAL

Resumo

O artigo analisa os votos dos ministros e o debate do plenário no julgamento da Arguição de Descumprimento de Preceito Fundamental 54 (ADPF 54) realizado no Supremo Tribunal Federal, nos dias 11 e 12 de abril de 2012, que discutiu a autorização para aborto em caso de gestação de feto anencefálico, chamada de "antecipação terapêutica do parto". O julgamento constitui parte da controvérsia sobre o direito ao aborto na sociedade brasileira. Sua análise revela que as diferentes posições no debate, na defesa do direito do feto anencefálico à vida, ou na direção da autonomia reprodutiva das mulheres, estão ancoradas na configuração individualista de valores.

Palavras-chave: Aborto, Supremo Tribunal Federal, ADPF 54, Anencefalia, Direitos humanos.
THE RIGHT TO ABORTION IN

CASES OF ANENCEPHALY: AN

ANTHROPOLOGICAL ANALYSIS

OF THE ADPF 54 TRIAL BY THE

SUPREME FEDERAL COURT

\section{Abstract}

The article analyses the arguments of the justices and the debates that took place during the plenary session of the Supreme Federal Court (Brazil) in the trial of the Accusation of Non-Compliance with a Fundamental Precept (ADPF 54) that took place on April 11th and 12th 2012. The trial discussed the authorization of abortions in cases of fetal anencephaly, called "therapeutic anticipation of birth". The trial is an aspect of the controversy surrounding the right to abortion in Brazilian society. An analysis of the proceedings reveals that the different arguments on the issue, whether upholding the fetus's right to life or tending towards the reproductive autonomy of women, were anchored in an individualistic configuration of values.

Keywords: abortion, Federal Supreme Court (Brazil), ADPF 54, anencephaly, human rights. 


\author{
EL DERECHO AL ABORTO EN CASO \\ DE ANENCEFALIA: UN ANÁLISIS \\ ANTROPOLÓGICO DEL JUICIO \\ DE ADPF 54 REALIZADO POR EL \\ SUPREMO TRIBUNAL FEDERAL
}

\title{
Resumen
}

El artículo analiza los votos de los magistrados y el debate del plenario en el juicio del Arreglo de Incumplimiento de Precepto Fundamental 54 (ADPF 54) realizado en el Supremo Tribunal Federal los días 11 y 12 de abril de 2012, que discutió la autorización del aborto en caso de anencefalia fetal, llamada de "anticipación terapéutica del parto". El juicio forma parte de la controversia sobre el derecho al aborto en la sociedad brasileña. Su análisis revela que las diferentes posiciones en el debate, en la defensa del derecho del feto anencefálico a la vida, o en la dirección de la autonomía reproductiva de las mujeres, están ancladas en la configuración individualista de valores.

Palavras clave: aborto, Supremo Tribunal Federal (Brasil), ADPF 54, anencefalia, derechos humanos. 